\title{
AC 2012-4673: RECOMMENDING HYDROGEN FUEL CELL RETROFITS FOR FORKLIFTS IN ENERGY AUDIT REPORTS BY INDUSTRIAL AS- SESSMENT CENTERS
}

\section{Ms. Lynn Albers, North Carolina State University}

Lynn Albers received her B.S. in mathematics with a minor in music from the Massachusetts Institute of Technology in 1992 and her M.S. in mechanical engineering with a concentration in nuclear engineering at Manhattan College in 1996. After working for Nortel Networks and the North Carolina Solar Center, Albers matriculated at North Carolina State University, where she is a Ph.D. candidate in mechanical engineering. Her dissertation spans the Colleges of Engineering and Education and will be the first of its kind at NCSU. In addition, Albers project manages the NCSU MAE State Energy Internship and Fellowship Program under the direction of Dr. Stephen Terry. To date, the program has 35 interns under the mentorship of energy engineers in both the private and public sectors. When available, Albers assists with energy assessments for both the program and the Industrial Assessment Center. 


\title{
Recommending Hydrogen Fuel Cell Retrofits for Forklifts in Energy Audit Reports by Industrial Assessment Centers
}

\begin{abstract}
Industrial Assessment Centers (IAC) are sponsored by the U.S. Department of Energy and are located in 24 universities throughout the country. They provide small and medium sized manufacturers no cost energy assessments performed by university graduate students and advanced undergraduate students. This is a win-win situation; the manufacturing plants receive a (free) report detailing ways to save energy while the student receives valuable, hands-on training in energy efficiency. The IAC located at North Carolina State University performs approximately twenty audits per year and incorporates renewable energy recommendations whenever possible. As companies implement the recommendations made by the IAC, there is a continuous need to find new opportunities for energy savings. The inspiration for the hydrogen fuel cell retrofit recommendation came while touring Ballard, a hydrogen fuel cell manufacturer, during the 2011 ASEE Conference in Vancouver, Canada. The tour was arranged and sponsored by the Energy Conversion and Conservation division.
\end{abstract}

To date, several hydrogen fuel cell retrofit recommendations have been attempted for various manufacturers. This paper will present the attempts at creating a feasible recommendation suggesting a hydrogen fuel cell retrofit for battery powered forklifts. These attempts will be presented as three case studies each representing a different manufacturer. The case studies will show the calculation of energy savings, cost savings and implementation costs associated with making a hydrogen fuel cell

recommendation. Writing the recommendation is also an excellent learning opportunity for the student who matriculates in the Mechanical Engineering department. Writing a recommendation of this type challenges the student to learn about the chemical reaction associated with hydrogen fuel cells, the processes associated with the production of hydrogen gas, and the equations necessary to calculate the electrical usage associated with charging stations.

\section{Industrial Assessment Centers}

Industrial Assessment Centers (IAC) were first established in 1976 as an initiative under the National Energy Strategy. Funded by the United States Department of Energy's Industrial Technologies Program now referred to as the Advanced Manufacturing Office ${ }^{5}$, the program has grown from four centers in 1976 to 24 centers nationwide in 2012. Field Managers at the Center for Advanced Energy Systems at Rutgers, the State University of New Jersey oversee the 24 centers.

The centers provide small and medium sized manufacturers no cost energy assessments performed by university graduate students and advanced undergraduate students under the direction of a faculty member. This is a win-win situation; the manufacturing plants receive a (free) report detailing recommendations to save energy while the student receives valuable, hands-on training in energy efficiency. As of January 2012, altogether they have performed 15,240 assessments and made 114,298 energy saving recommendations. ${ }^{4}$ 
The IAC located at North Carolina State University (NCSU) ${ }^{6}$ was established in 1992 under the direction of Dr. Herbert Eckerlin and continues today under the direction of Dr. Stephen Terry. At any given time, the IAC team will consist of 2-5 graduate students on a research assistantship and 2-5 undergraduate students on biweekly payroll. The NCSU IAC solicits requests from manufacturers in North Carolina, South Carolina and Virginia to visit their facility and perform an energy assessment. Typically the director will travel with a combination of 3-5 graduate and undergraduate students to the site where the team will receive a tour of the facility, an explanation of the process and time to take measurements. The team will then return to the university and prepare energy and cost saving recommendations to be included in the assessment report that will be delivered to the site's energy manager approximately eight weeks later. The report is also submitted to the national IAC database which is maintained by the team at Rutgers University. At the time of this paper, the NCSU IAC completed a total of 441 assessments containing an average of 7.5 recommendations per assessment for a total of 3,318 recommendations with average savings listed in Table $1 .^{4}$

Table 1. Average Recommended Savings Per Assessment; The North Carolina State University IAC ${ }^{4}$

\begin{tabular}{|c|c|c|c|}
\hline $\begin{array}{l}\text { Average Recommended } \\
\text { Savings Per Assessment }\end{array}$ & Usage Reduction & \% Reduction & Cost (\$) Savings \\
\hline All Energy & $15,131 \mathrm{MMBtu}$ & $7.23 \%$ & $\$ 85,674$ \\
\hline Electrical & $606,034 \mathrm{kWh}$ & $4.93 \%$ & $\$ 26,552$ \\
\hline Natural Gas & $4,982 \mathrm{MMBtu}$ & $15.00 \%$ & $\$ 34,926$ \\
\hline Waste & & & $\$ 10,425$ \\
\hline Productivity & & $\$ 75,733$ \\
\hline \hline Total & & $\$ 171,832$ \\
\hline
\end{tabular}

Of the 3,318 recommendations, companies have implemented 1,413 for an implementation rate of $42.58 \%$ and an average of 3.5 recommendations per assessment. The average implemented savings per assessment are listed in Table 2 . $^{4}$

Table 2. Average Implementated Savings Per Assessment; The North Carolina State University IAC

\begin{tabular}{|c|c|c|c|}
\hline $\begin{array}{r}\text { Average Implemented } \\
\text { Savings Per Assessment }\end{array}$ & Usage Reduction & \% Reduction & Cost (\$) Savings \\
\hline All Energy & $3,696 \mathrm{MMBtu}$ & $1.83 \%$ & $\$ 25,449$ \\
\hline Electrical & $206,570 \mathrm{kWh}$ & $1.77 \%$ & $\$ 9,789$ \\
\hline Natural Gas & $1,240 \mathrm{MMBtu}$ & $3.76 \%$ & $\$ 9,276$ \\
\hline Waste & & & $\$ 2,199$ \\
\hline Productivity & & $\$ 24,005$ \\
\hline Total & & $\$ 51,653$ \\
\hline
\end{tabular}

The Industrial Assessment Center provides an opportunity for students to see real-world applications of the theory they learn in the classroom when they attend a site visit. Often, this is the first exposure that the students have to industrial size compressors, pumps, boilers, chillers and air handling units. Then, through the preparation of the recommendations, the students apply the knowledge they gained in junior level classes such as Principles of Electrical Engineering, Thermodynamics, Heat Transfer, and Fluids as well as senior level electives such as Energy Conservation in Industry, Design of Solar Thermal Systems, and Advanced Air Conditioning Design and solidify their understanding of this material. The majority of the learning occurs when the student calculates and communicates the energy savings in the 
recommendation. In this process, the student learns how to assess where the energy savings occur, calculate how much energy is saved, and determine if the savings are feasible by providing a realistic payback period. The majority of the calculations are done by hand or in Excel. If applicable, tools such as Carrier's Hourly Analysis Program (HAP), or the National Renewable Energy Laboratory's TMY3 data and PVWatts ${ }^{\mathrm{TM}}$ Grid Data Calculator (Version 2) are used to assist with calculations.

As companies implement the recommendations made by the IAC, there is a continuous need to find new opportunities for energy savings. Whenever possible, the center tries to incorporate renewable energy recommendations. Usually, these recommendations, while helpful to the environment, do not have feasible payback periods and are merely presented as suggestions to the manufacturing plants. For example, electric generation from rooftop photovoltaic systems has been suggested but it has a payback period of 30 years or 20 years if the electric provider has an electric buy back program.

The inspiration for the hydrogen fuel cell retrofit recommendation came while touring Ballard, a hydrogen fuel cell manufacturer, during the 2011 ASEE Conference in Vancouver, Canada. The tour was arranged and sponsored by the Energy Conversion and Conservation division. Upon touring the facility and receiving a thorough overview of the products and history of PEM (Proton Exchange Membrane) fuel cell development, the author was inspired to write a feasible recommendation to retrofit existing, battery powered forklifts with hydrogen fuel cells. The success of this type of recommendation would satisfy two goals; provide a new recommendation that could be incorporated in future assessments and have a feasible recommendation utilizing renewable, clean energy.

The Industrial Assessment Center is an excellent pedagogical avenue that provides opportunities to broaden and apply one's knowledge base to discover new areas of energy savings. This paper will show this by presenting the author's attempts at creating a feasible, hydrogen fuel cell retrofit for battery powered forklift recommendation. These attempts will be presented as three case studies each representing a different manufacturer. The author attended the site visit with the IAC team for case studies 1 and 3 while an IAC teammate visited and compiled the data for case study 2. The progression of case studies are intended to depict the learning that occurs and the difficulties that arise when preparing the recommendation; all of which are excellent training for the real world.

\section{Forklift Retrofits in Theory}

For this endeavor, we focused on electric, battery-powered riding forklifts and did not pursue retrofitting pallet jacks, tuggers or walkie riders. A riding forklift is one in which the driver either sits or stands in the vehicle while operating it. Internal Combustion Engine (ICE) forklifts are another type of forklift that are more commonly used for outdoor operations due to the emissions from the exhaust. The total number and type of forklift factory shipments according to the Industrial Truck Association are depicted in Figure 1. Electric rider forklifts compose approximately $30 \%$ of the total shipments ${ }^{8}$ which shows that a large market exists for potential retrofits. 


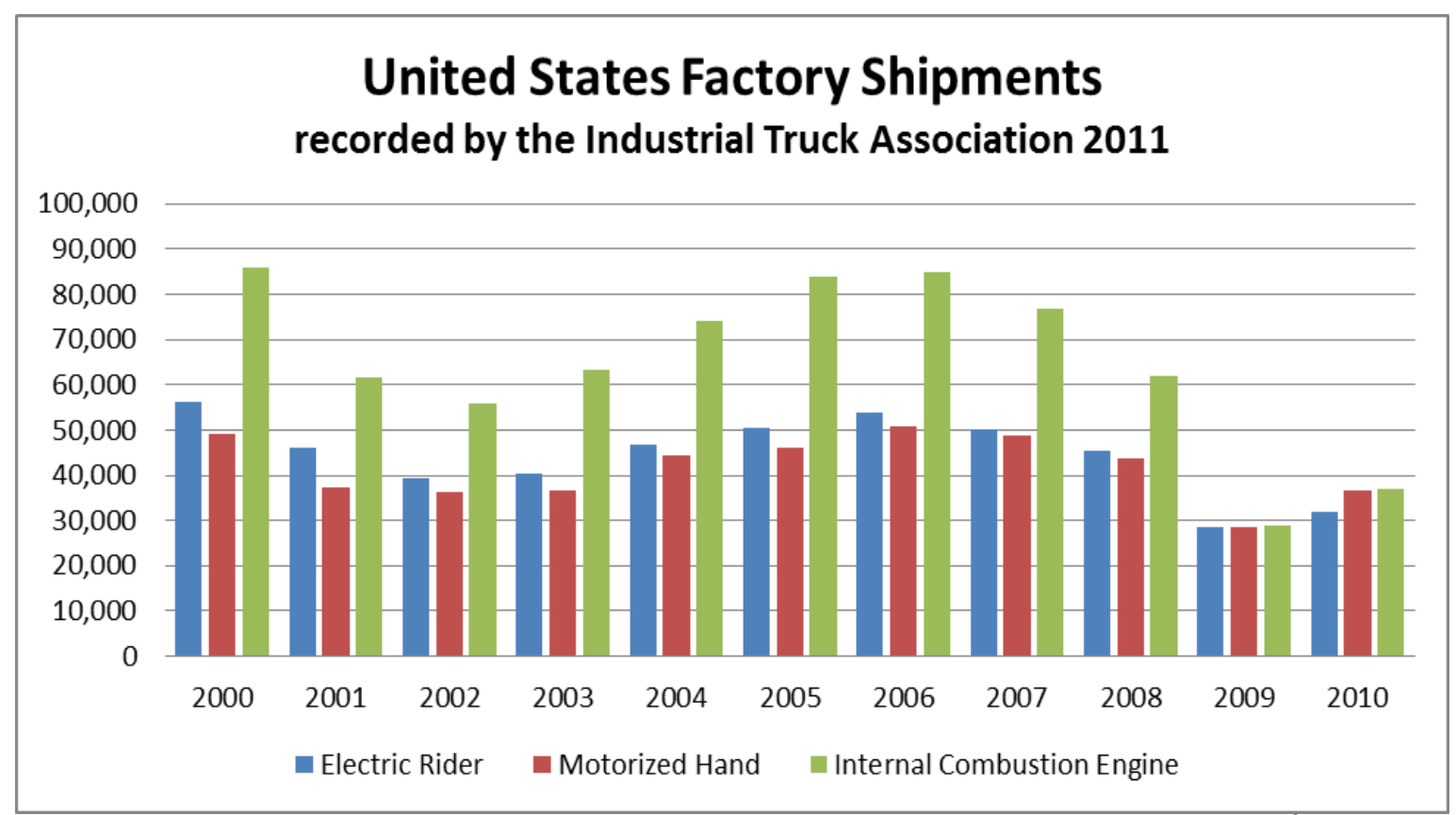

Figure 1. U.S. Factory Shipments for Electric Rider, Motorized Hand and ICE forklifts ${ }^{8}$

It is claimed that fuel-cell powered forklifts have the following advantages over the battery-powered types they replace. ${ }^{2}$

1. Higher productivity by eliminating time-consuming battery changing

2. Can be refueled in less than 5 minuets

3. Space required for fueling is much smaller than that required for a battery room

4. Fuel cells maintain a constant voltage, without the voltage drop towards end of shift or in cold locations, as observed in batteries

5. No environmental concerns from acid runoff or lead, or from tailpipe emissions

The scope of IAC recommendations is limited to energy savings and lean manufacturing savings opportunities. Therefore, advantage 5 above is considered outside the scope of an IAC assessment and was not addressed in the recommendation or within this paper. However, it is a valid and important concern that can be quantified for future calculations. In addition, we decided to simplify the recommendation by focusing on energy, materials, and maintenance savings only. Therefore, lean manufacturing savings were not incorporated into the recommendation. Thus, savings due to space reduction (\#3) and the benefits of constant voltage (\#4) were not considered. For the hydrogen fuel, a flat value of $\$ 8$ per $\mathrm{kg}$ was used. This decision was based on the assumption that the hydrogen fuel was produced from natural gas via steam reforming off-site and delivered by truck in tanks fit to go directly onto the forklift. ${ }^{1}$

\section{Case Studies}

Three plants utilizing forklifts were visited and a hydrogen fuel cell retrofit recommendation was attempted for each. Each experience is presented below as a case study. The focus was primarily on determining the number of electric, battery powered forklifts that could potentially be retrofitted with hydrogen fuel cells. 


\section{Case Study 1}

For Case Study 1, we visited a plant with 270,000 sqft of floor space, 275 employees and 2,750 hours of production per year. There wasn't a great demand for forklifts and therefore, the plant leased approximately 20 electric, battery powered forklifts that were split equally between their warehouse and manufacturing locations (Table 3.). Because this was our first attempt at a hydrogen fuel cell recommendation, we weren't prepared to ask the necessary questions and datalog the chargers while at the site. Therefore, a great deal of the information was acquired post site visit.

Table 3. Summary of electric, battery-powered forklifts for Case Study 1

\begin{tabular}{||l|l|l|l|l||}
\hline \hline Location & Forklift Type & \# Forklifts & \# Batteries per Forklift & Battery Volts \\
\hline \hline Manufacturing & Electric Rider & 10 & 2 & 48 \\
\hline Warehouse & Electric Rider & 10 & 2 & 48 \\
\hline \hline Total & & 20 Electric & & \\
\hline
\end{tabular}

The electric demand $(\mathrm{kW})$ and demand cost (\$/yr.) savings were calculated by multiplying the number of chargers potentially utilized at one time by the rated voltage and amperage and then dividing by 1,000 to get $\mathrm{kW} /$ month. This value was then multiplied by 12 months and the cost $/ \mathrm{kW}$ to obtain the annual demand cost savings. ${ }^{7}$

The electric usage $(\mathrm{kWh})$ and electric energy cost (\$/yr.) savings were calculated by assuming the forklifts have a 48V, $450 \mathrm{amp}$ hour lead acid batteries, with a 75\% discharge (approximately 6 hours of operating time) between re-charging every day. Using a standard industrial charger with a $48 \mathrm{~V}, 50 \mathrm{amp}$ output, the recharge time was approximated by dividing the amp hours to be replaced by $90 \%$ of the rated output of the charger. ${ }^{7}$ This gave us an average recharge time per day per forklift that could then be used to calculate how many hours per year of charging were required per forklift. This yearly charging time multiplied by the number of forklifts times the power resulted in the annual $\mathrm{kWh}$ electric usage which multiplied by the cost/kWh gave the annual electric energy cost savings. ${ }^{7}$

While one can realize energy and cost savings from reduced electric usage, this savings is overcome by the cost of the hydrogen. While there were many options for calculating the cost of hydrogen, we decided to use what we felt was the most readily available and easily acclimated form of the fuel. Therefore we used a flat rate of $\$ 8 / \mathrm{kg}$ of hydrogen. ${ }^{1}$ This cost included production, delivery and on site storage. We estimated that each fuel cell requires $100 \mathrm{~L} / \mathrm{min}$ of fuel and $1 \mathrm{~kg} \mathrm{of} \mathrm{H}_{2}$ is equivalent to 11,126 L. $^{7}$

For this case study, the cost of the hydrogen was twice that of the electric energy cost savings. Therefore, the challenge was how to offset the hydrogen fuel cost. Thus, we turned to advantage \#1 listed above: eliminate time consuming battery changing. We estimated the amount of time it would take for an employee to remove a battery, set it in a charger and replace it with a charged battery so that the forklift could continue operating. The labor savings associated with this helped make the recommendation feasible and offset the hydrogen fuel cost. However, upon consulting the on site energy manager, we found that this didn't happen in practice. The reality is that the batteries are not removed from the forklift for charging. The forklifts are merely backed up to the charger and plugged in. This takes a total of 30 seconds of time by the operator of the forklift. So, there are no time 
consuming battery changes and there are no savings associated from advantage \#1. We found this to be true in cases 2 and 3 as well. Therefore, we scrapped this line item from the recommendation.

Once we scrapped the savings from eliminating time consuming battery changes, we needed to find another way to offset the hydrogen fuel cost. Thus, we looked at a leasing cost reduction. Battery powered forklifts require recharging every six hours and therefore during an 11-hour workday, only half the fleet can be used whiles the other half charges. Hydrogen fuel cells only require a 5 minute refueling time and thus the same forklifts can be used throughout the day. This would cut the required number of forklifts in half and thus reduce the leasing costs. ${ }^{7}$ The leasing cost per forklift was significant but unfortunately, these savings alone were not sufficient to offset the hydrogen fuel cost deficit.

In order to further help overcome the cost of the hydrogen fuel, we looked at material cost savings associated with hydrogen fuel cells. The average life of a lead acid battery is approximately 5 years at a cost of approximately $\$ 5,500$ and each forklift contained two batteries. While the average life of a hydrogen fuel cell stack is approximately 10 years at a cost of approximately $\$ 10,000$ and each forklift would contain one stack. For the fleet in this case study, the yearly material cost of the hydrogen fuel cell is approximately $24 \%$ that of the lead acid batteries thus resulting in significant savings. ${ }^{7}$ So, for this case study, the leasing cost reduction combined with the material cost savings offset the hydrogen fuel cost to give a positive total savings.

The cost to replace the lead acid batteries with hydrogen fuel cells is about $\$ 10,000$ per forklift as estimated by Ballard. The labor cost for installing this system was estimated at $\$ 200$ per forklift." "The U.S. Federal Government offers an investment tax credit of $30 \%$ for qualified fuel cell property or $\$ 3,000 / \mathrm{kW}$ of the fuel cell nameplate capacity, whichever is less." 3 The implementation cost divided by the total savings gave a payback period of 4.3 years for this case study.

\section{Case Study 2}

For Case Study 2, we visited a plant with 330,000 sqft of floor space, 70 employees and 4,250 hours of production per year. The plant utilized a mixture of electric riders, tuggers, and walkie riders totaling a fleet of 46 forklifts as shown in Table 4. This time, we decided to datalog the forklifts and record the amperage of all 46 forklifts 
Table 4. Summary of electric, battery-powered forklifts for Case Study 2

\begin{tabular}{||c|c|c|c|c|c|c||}
\hline \hline Location & Forklift Type & \# Forklifts & $\begin{array}{c}\text { \# Batteries } \\
\text { per Forklift }\end{array}$ & $\begin{array}{c}\text { Battery size } \\
\text { (inches) }\end{array}$ & $\begin{array}{c}\text { Battery } \\
\text { Amph }\end{array}$ & $\begin{array}{c}\text { Battery } \\
\text { Volts }\end{array}$ \\
\hline \hline Warehouse & $\begin{array}{c}\text { High } \\
\text { reachers }\end{array}$ & 10 & 2 & 16 & 700 & 36 \\
\hline & $\begin{array}{c}\text { High } \\
\text { reachers }\end{array}$ & 2 & 2 & 18 & 900 & 36 \\
\hline & Order pickers & 7 & 2 & 16 & 700 & 36 \\
\hline & Order pickers & 2 & 2 & 14 & 650 & 36 \\
\hline & Pacers & 2 & 2 & 22 & 1,250 & 36 \\
\hline & Pacers & 2 & 2 & 20 & 1,000 & 36 \\
\hline & Pacers & 2 & 2 & 18 & 900 & 36 \\
\hline & Tuggers & 9 & 2 & 16 & 700 & 36 \\
\hline & $\begin{array}{l}\text { Walkie } \\
\text { Riders }\end{array}$ & 7 & 2 & 16 & 700 & 36 \\
\hline & Side logger & 2 & 2 & 18 & 850 & 36 \\
\hline & Multishifter & 1 & 1 & 16 & 700 & 36 \\
\hline & Total & 46 Electric & & & & \\
\hline
\end{tabular}

The current transducer was placed around the electric supply to the panel that provided the electricity for all the chargers for the entire fleet of 46 forklifts. The datalogger recorded unusually low amperage leading us to believe that it was either programmed incorrectly or that some other mishap had occurred. As a result, the electric demand and usage savings were extremely low; not representative of 46 forklifts. In addition, the facility owned almost the entire fleet of forklifts thereby eliminating any chance of overcoming the high hydrogen fuel cost with a leasing cost reduction and producing a positive total savings. Therefore, we abandoned this recommendation.

\section{Case Study 3}

For Case Study 3 we visited a plant with a total of 390,000 sqft of floor space between the plant and warehouses, 300 employees and 6,000 hours of production per year. The plant utilized a mixture of electric riders and propane riders as shown in Table 5. Nine of the fifteen electric riders in warehouse 2 were data logged and used in the recommendation.

Table 5. Summary of electric, battery-powered forklifts for Case Study 3

\begin{tabular}{||l|l|l|l|l|l||}
\hline Location & Forklift Type & \# Forklifts & $\begin{array}{l}\text { \# Batteries / } \\
\text { Forklift }\end{array}$ & Battery Volts & Leased \\
\hline \hline Warehouse 1 & Propane Rider & 20 & 0 & & Yes \\
\hline Warehouse 2 & Electric Rider & 15 & $3-12$ Volt & 36 & Yes \\
\hline Total & & 35 & & & \\
\hline
\end{tabular}

The current transducer was placed around one phase for one of the nine chargers in warehouse 2. This time, the data logger gave us reasonable results and reasonable electric demand and usage savings were calculated. However, without a leasing cost reduction line item, the recommendation was still not feasible and therefore was not included in the final assessment. 


\section{Conclusion}

Writing the hydrogen fuel cell retrofit recommendation was an excellent learning opportunity. What seemed at first to be a very simple recommendation, turned out to be in fact very difficult and disappointing. For the Mechanical Engineering student, this was a great introduction to PEM (proton exchange membrane) fuel cells which is a topic not frequently covered in the classroom. In addition, it was a great opportunity to renew an understanding of power, charging stations and how to calculate their electrical usage. What was not expected was the exposure to the numerous processes and options associated with hydrogen fuel production. This was a pleasant surprise and one area that deserves more investigation. It is possible that another form of hydrogen fuel production, such as on site generation, may be more economically feasible and help improve the total savings of the recommendation.

The greatest lesson learned and perhaps the most disappointing revelation was the realization that the "higher productivity by eliminating time-consuming battery changing" could not be utilized in the recommendation. The economic feasibility of the hydrogen fuel cell retrofit is very dependent on this savings. If a plant has a designated person that removes batteries, charges them and returns them to the forklift, then this savings will be recognized. However, the three facilities that we observed did not have this process. In fact, the act of backing the forklift up to the charger and plugging it in takes less time than refueling a hydrogen fuel cell.

Without the "time-consuming battery changing" savings, the success of the hydrogen fuel cell retrofit recommendation becomes contingent upon three factors: a leasing cost reduction, the material cost savings and the total energy costs. If the forklifts are leased, then there is a possibility that total savings can be realized if the lease ends within a reasonable length of time and if the operations dictate a reduction in the fleet of forklifts is possible. Note that future analysis could be done to estimate the optimal "reasonable length of time" within which the lease should end and what percentage of the fleet should be reduced to make the recommendation feasible.

The total energy costs are a function of the electric energy savings minus hydrogen fuel production costs. There will be a reduction of electric demand and usage but this is minimal compared to the cost of the hydrogen fuel. For Case Study 1, the electric energy savings were 50\% of the hydrogen fuel cost and for Case Study 3, the electric energy savings were $10 \%$ of the hydrogen fuel cost. There are too many variables in the two case studies to say whether the values in Case Study 1 are more realistic than Case Study 3 or vice versa. More site visits with proper data logging to obtain more accurate energy usage are necessary in order to give a better statistical sample and enable a proper statistical analysis.

One can argue against this recommendation by stating that energy is not being saved but merely exchanged from one form to another. However, advantage number 5 listed above, "No environmental concerns from acid runoff or lead, or from tailpipe emissions" is a valid and quantifiable savings that gives hydrogen fuel cells the advantage over batteries. Elgowainy et al have analyzed the fuel cycle impacts of hydrogen fuel cell vs. batteries vs. ICEs using the GREET model. The fuel cycle includes initial recovery and processing of the primary energy, conversion to the form used by the forklift and use at the forklift. Overall, the fuel cycle total energy use is less (or more efficient) for hydrogen fuel cells than batteries and ICEs. ${ }^{2}$ 


\section{Acknowledgements}

The author is sincerely grateful to the Energy Conversion and Conservation Division for the invitation to tour Ballard during the 2011 ASEE Conference in Vancouver, Canada. It was a great experience and one that will hopefully be repeated at each conference. The author also wishes to thank the directors of the Industrial Assessment Center at North Carolina State University for their support and assistance with this new recommendation.

\section{References}

[1] Blencoe, Greg. "Cost of Hydrogen from Different Sources." Hydrogen Car Revolution. N.p., 9 Nov. 2009. Web. 22 June 2011. <http://www.h2carblog.com/?p=461>.

[2] Elgowainy, A., Gaines, L., \& Wang, M. (2009). Fuel-cycle analysis of early market applications of fuel cells: Forklift propulsion systems and distributed power generation. International Journal of Hydrogen Energy, 34(9), 3557-3570.

doi:10.1016/j.ijhydene.2009.02.075

[3] "Financial Incentives for Hydrogen and Fuel Cell Projects." Fuel Cell Technologies Program. U.S. Department Of Energy; Energy Efficiency And Renewable Energy, 8 Nov. 2011. Web. 9 Jan. 2012.

<http://www1.eere.energy.gov/hydrogenandfuelcells/incentives.html>.

[4] "IAC Database." Industrial Assessment Centers Database. U.S. Department Of Energy; Energy Efficiency And Renewable Energy, 10 Jan. 2012. Web. 10 Jan. 2012. <http://iac.rutgers.edu/database>.

[5] "Industrial Assessment Centers." Advanced Manufacturing Office. USDOE Energy Efficiency And Renewable Energy, 1 Feb. 2012. Web. 16 Mar. 2012. <http://www1.eere.energy.gov/manufacturing/tech_deployment/iacs.html>.

[6] "Industrial Assessment Center." Department Of Mechanical And Aerospace Engineering. North Carolina State University, 1 Jan. 2012. Web. 16 Mar. 2012. 〈http://www.mae.ncsu.edu/iac/>.

[7] "Energy Conservation Report NC-0432." Industrial Assessment Centers Database. DOE Energy Efficiency And Renewable Energy, 30 July 2011. Web. <http://iac.rutgers.edu/database/assessment/NC0432>.

[8] "U.S. Shipments Table \& Graph." Marketing Information. Industrial Truck Association, 2011. Web. 9 Jan. 2012. $<$ https://www.indtrk.org/marketing.asp>. 